\title{
Use and treatment of olive mill wastewater: Current situation and prospects in Spain
}

\author{
By J.A. Fiestas Ros de Ursinos and R. Borja Padilla \\ Instituto de la Grasa y sus Derivados (C.S.I.C.) \\ Avda. Padre García Tejero, n.ำ 4, 41012 - SEVILLA
}

\section{RESUMEN}

Utilización y tratamiento del alpechín: situación actual y perspectivas en España.

Las características de los alpechines se establecen desde el punto de vista de su capacidad contaminante y de los problemas típicos que surgen en las zonas de cultivo del olivo. También están descritas las soluciones de la administración del Estado para la prevención de la contaminación de aguas de superficie.

Se detallan especialmente los puntos de acción incluidos dentro de un programa de Investigación y Desarrollo financiado por el Gobierno Español y la CEE a través de la comisión MEDSPA 89, para la evaluación técnica y económica de diferentes sistemas de eliminación y tratamiento de alpechines, con el fin de determinar la conveniencia de su introducción a nivel industrial.

Al mismo tiempo se describen los sistemas actuales sometidos a evaluación:

- Intensificación de la evaporación natural de alpechines almacenados en balsas.

- Procesos físicos de evaporación forzada para eliminar este agua residual, seguido de procesos biológicos aerobios o sistemas de ultrafiltración y ósmosis inversa para el tratamiento final de los condensados (dos sistemas).

- Aplicación de procesos físico-químicos para eliminar la mayor parte de la materia orgánica del alpechín, y uso de procesos biológicos aerobios o sistemas de ultrafiltración y ósmosis inversa para el tratamiento final de la fraccción clarificada (tres sistemas).

- Proceso biológico para la depuración integral del alpechín mediante la aplicación sucesiva de los procesos: bioconversión, biometanización, tratamiento aerobio, y tratamiento físico-químico. Se consiguieron rendimientos del orden del $99,6 \%$, con la obtención simultánea de subproductos de interés comercial (un sistema).

PALABRAS-CLAVE: Alpechín - España - Información (articulo) - Situación actual - Tratamiento - Utilización.

\section{SUMMARY}

Use and treatment of olive mill wastewater: current situation and prospects in Spain.

The characteristics of olive mill wastewater are set out the viewpoint of their pollutant capacity and the problems arising from their tipping in olive-growing areas. The national administration's solutions for preventing pollutions of surface waters are also stated.

Special detail is given to the action taken within a research and development program financed by the Spanish Gobernment and the EEC through the Comission MEDSPA 89 for the technical-economic evaluation of different systems for eliminating and treating olive mill wastewater, in order to determine the teasibility of their introduction at industrial level. bed:

At the same time the systems currently under evaluation are descri-

- Intensification of natural evaporation from olive mill wastewater stored in ponds (two systems)
- Physical processes using forced evaporation to eliminate the olive mill wastewater, followed by aerobic biological processes or systems of ultrafiltration and inverse osmosis for final treatment of the condensate (two systems).

Application of physico-chemical processes to eliminate the greater part of the organic components of the olive mill wastewaters and the use of aerobic biological processes or systems of ultrafiltration and inverse osmosis for final treatment of the clarified fraction (three systems).

Biological process for the complete treatment of the olive mill wastewaters by the successive application of processes: bioconversion, biomethanisation, aerobic treatment, and physico-chemical treatment. Treatment yields of the order of $99,6 \%$ are achieved, at the same time obtaining by-products of commercial interest (one system).

KEY-WORDS: Current situation - Information (paper) - Olive mill wastewater - Spain - Treatment - Use.

\section{INTRODUCTION}

Environmental pollution from wastes produced by human activity has become an universal problem for society, forcing it to fight against the factors which change and interfere with its life medium.

In the countries of the Mediterranean Basin, the environmental pollution caused by the wastewaters from the olive oil industry stands out by its size and severity with a volume of up to 10 millions $\mathrm{m}^{3} / \mathrm{year}$.

\section{CHARACTERISTICS OF THE OLIVE MILL WASTEWATERS}

\subsection{Composition}

The elaboration of olive oil yields an oily liquor $(20 \%)$, a solid residue (30\%) and an aqueous liquor $(50 \%)$. The latter comes from the vegetable water of the fruit, and its composition is shown in Figure 1 (1). This vegetable water, combined with the washing waters from olive processing, makes up what is generally known as "alpechines" (olive mill wastewaters, OMW). It also contains soft tissue from the olive flesh, and oil in very stable emulsion. Its composition is very variable and depends mainly on the system used in obtaining the olive oil. Thus while wicker mats is very small or none, around 1 litre of water $/ \mathrm{kg}$ of olive is used in the continuous systems. 


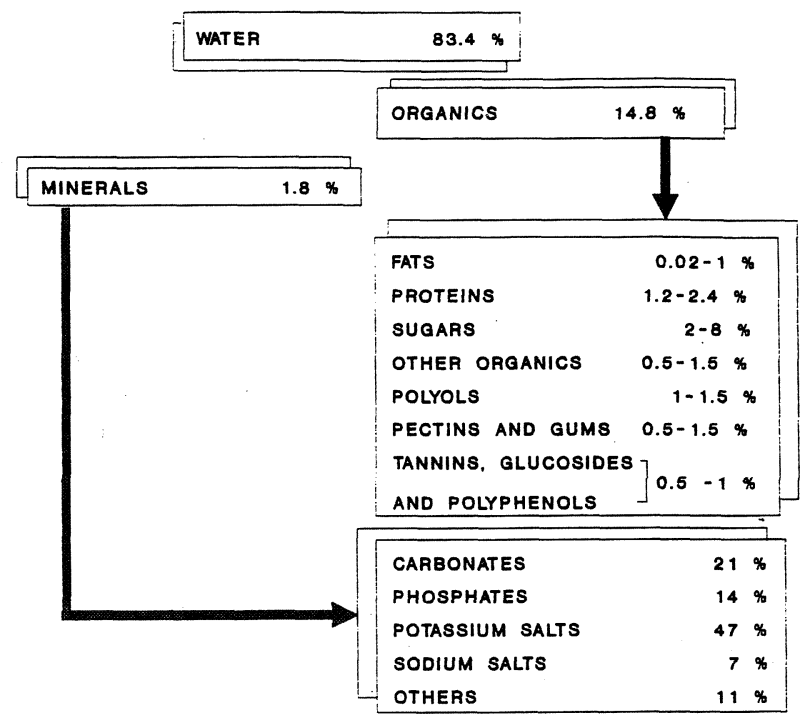

Major polyphenols

Caffeic; Vanillic; Coumaric; 1-Caffeil Glucose; Hydroxytirosol; Oleuropein 4-Hidroxitirisol Monoglucoside; Tirosol; Luteolin; Quercetin; Dihydrocaffeic: Dihydroxycinnamic; Protocatechuic; Pyrocatechine; Cinnamic; phydroxybenzoic; 3, 4, 5-trimethoxybenzoic; Veratric.

Figure 1

Composition of the olive mill wastewater (OMW)

\subsection{Biological characteristics}

The concentration of microorganisms in the OMW is of the order of $105 / \mathrm{ml}$. The most common are "Pseudomonas" or microorganisms related by their capacity to transform compounds considered to be recalcitrant. Yeasts of "Sacharomyces" type and the moulds "Penicillium glaucum" and "Aspergillus niger" are also found (2).

The presence of phenolic compounds results in antimicrobial activity, which obstructs the biological processes in its treatment. Of the different studies on the antimicrobial activity of OMW, those of most interest are the following: (2) (3) (4) (5) (6) (7) (8) (9) (10) (11) (12) (13) (14) (15) (16) (17) (18) (19).

It has a phytotoxic action on plant germination (20) (21). It shows a slight hormonal activity on containing abscissic acid $(0,36-0,53 \mu \mathrm{g} / \mathrm{l})$ which governs fruit abscission and also has an influence on germination and senescence (22). It shows a toning effect and vasodilator and hypotensor activity (23). Its $\mathrm{LD}_{50}$ toxicity for fish is $8,7 \%$ after 24 hours (24)

\subsection{Physico-chemical characteristics}

- $\mathrm{pH}: 4,5-5$.

- Very complex redox system.

- High buffer capacity.

- Surface tension around $40 \mathrm{erg} / \mathrm{cm}^{2}$.

- Interface tension of some $10 \mathrm{erg} / \mathrm{cm}^{2}$.

- Lyophil-type colloidal system.

Thus it behaves as a tension-active solution of great stability, presenting polarisation phenomena in the interphase (25). This interferes with the application of ultrafil- tration and inverse osmosis systems for the separation of its components (26) (27) (28).

\subsection{Pollutant capacity}

Table I shows the characteristics of the OMW in terms of their pollutant capacity (29). In view of the numerous substances found in OMW, many of the research projects for its treatment have been aimed at the possible reuse of these components to reduce the cost of elimination or treatment, or to make the process profitable.

Table I

Characteristics of olive mill wastewater with respect to its pollutant capacity

Parameter

Press mill Continuous mill

$\mathrm{pH}$

COD

4,5-5

$120-130$

$4,7-5,2$

BOD

S.S. (solids in suspension)

90-100

T.S. (total solids)

M.S. (mineral solids)

V.S. (volatile solids)

1

120

15

105

$0,5-1,0$

$35-48$

60

5

55

Fat

\section{SITUATION AND PROSPECTS IN SPAIN}

The olive oil industry was until some forty years ago made up of a large number of small mills. The greater part of their tippings, of little volume, was absorbed in the fields without reaching the public water supply.

When the process of industrialisation began by the $50 \mathrm{~s}$, cooperatives and industries were created with high milling capacity, and thus high OMW production. By the 70 s this had become the main source of pollution of the Guadalquivir Basin, the area of greatest olive concentration in Spain. For this reason, in 1981 the Government prohibited the tipping of OMW, and gave $100 \%$ subsidies for the works necessary to construct ponds for the storage and natural evaporation of the OMW, although not for the adquisition of the appropiate land.

The introduction of this system of evaporation ponds resulted in a marked improvement in the quality of the rivers. However, in 1986-87, cases were detected of tipping of OMW due to various deficiences in some ponds, mainly their insufficient capacity due to the substitution of the classic system of wicker mats by the continuous system. This latter produces more than double the volume of OMW per olive milled. At the same time, OMW ponds give off bad smells, creating a new environmental problem for the people living near them.

In view of both problems -the lack of storage capacity and the production of bad smells- a project was developed from 1989 for the "Technical-economic evaluation of different processes of elimination and treatment of OMW". 
This project, whose budget is some 2 million dollars, is $80 \%$ financed by the Spanish Government and the rest by the EEC, through the Commission of the Project MEDSPA'89, concerned with environmental protection.

The aim of this project is to try to solve the environmental problem caused by the tipping of OMW, by means of:

- The development at industrial level of systems for the treatment of OMW which offer clear possibilities of technical and economic feasibility.

- The experimentation by the installing company and later management by the staff of the mill, with any necessary advice.

- Their following-up for two years for both technical and economic evaluation.

Selection of the different systems to be developed and evaluated is conditioned by:

- The system should be developed at pilot plant level.

- It should be technically feasible and not use a very sophisticated technology.

- Its working should not require highly qualified staff.

- The aim of the process should be treatment.

- The plant to be installed should treat at least 100 $\mathrm{m}^{3} /$ day of fresh OMW or $25 \mathrm{~m}^{3}$ mature OMW (storage in ponds).

Eight methods have been selected, based on:

- Intensification of the natural evaporation capacity of the ponds.

- Thermal concentration.

- Physico-chemical treatment.

- Biological treatment.

\section{INTENSIFICATION OF THE NATURAL EVAPORA- TION CAPACITY OF THE PONDS}

4.1. Evaporation by means of sprinklers and panels - HBS System.

This consists of panels with a large surface of interchange, sprayed intermittently by a sprinkler. The panels are exposed to wind action and have an evaporation capacity 40 times greater than of a pond of the same surface area.

\subsection{Wind-powered hydro pump}

This consists of a wind-powered turbine pump floating on the pond surface. During its rotation it lifts sprinkler tubes which distribute the OMW over the pond as droplets, thereby increasing the surface area of the OMW to be evaporated.

\section{THERMAL CONCENTRATION}

5.1. Single effect forced evaporation: Biodestil Method

The process has been developed in Italy by the company Italimpresse. It consists of an evaporation of OMW (single effect) after neutralisation with $\mathrm{NaOH}$ solution. A concentrate is obtained in the form of a paste, and a condensate which undergoes an aerobic biological treatment to reduce the COD of the liquid waste.

\subsection{Double stage forced evaporation: Niro-atomi-} zer Method (Denmark).

This consists of a three-effect forced evaporation with flash system. A concentrate, which is added to the olive pressings, and a liquid condensate $(C O D=3.000-5.000$ ppm) are obtained. The latter needs a further treatment by inverse osmosis to reduce its pollutant capacity.

\section{PHYSICO-CHEMICAL TREATMENT}

\subsection{Fernando Saro Company Method.}

The process consists basically of a physico-chemical treatment followed by an aerobic biological treatment of the liquid effluent. It works as follows:

The OMW is treated with a flocculant and coagulant at appropiated dosage. The sludge which forms is separated by decanting, and the liquid effluent neutralised with $\mathrm{NaOH}$. Mineral nutrients are added, and the product recycled through an aerobic bacterial filter for its treatment. Sludge drying is by centrifugation, and treatment of the liquid effluent by ultrafiltration and inverse osmosis in place of the aerobic biological treatment.

\subsection{Saem-Indelpa Method}

This has been developed in Italy by the National Research Council and the firm Italimpresse. It consists of a physico-chemical treatment of flocculation-decantation, followed by treatment of the liquid effluent by inverse osmosis. The OMW is treated with calcium hydroxide and air is blown through. Polyelectrolytes are added, and the product is passed to a horizontal centrifuge or decanter. The sludge is collected in a container, and the liquid, after addition of $\mathrm{CO}_{2}$ and a period in a static decanter, is passed to the inverse osmosis apparatus.

\subsection{Scandiavision Method}

This has been developed by the Norwegian companies NIVA, CHK and TICON. The treatment is physico-chemical and consists of flocculation and coagulation in two phases. In the first, sludge is separated by flotation and in the second by filtration. The $\mathrm{pH}$ of the OMW is adjusted and a flocculant added at the head of a continuous phase and a coagulant at the tail. The product is passed to a decanter where the sludge which forms is separated. This is dried in a centrifuge and stored in a sludge tank. The liquid is treated with more flocculant and active carbon. It is filtered through a sand filter and passed to the ultrafiltration apparatus. 


\section{BIOLOGICAL TREATMENT: AN INTEGRAL TREAT- MENT OF OMW BY THE APPLICATION OF BIOLO- GICAL PROCESSES.}

As mentioned above, OMW contains high proportions of phenolic compounds, which are characterised by their great antimicrobial effect, and thus interfere with the application of biological processes for its treatment. At the same time, the studies made by (2), (15), (30), (31), (32), demonstrate that the polyphenols of OMW can be degraded by moulds and bacteria through enzymatic hydrolisis.

Following these lines of work, the Instituto de la Grasa y sus Derivados, CSIC (Seville), has developed a method of bioconversion to eliminate the polyphenols present in the OMW, using specific biological products, and which permits its later treatment (33).

Instituto de la Grasa y sus Derivados, CSIC, and Biotecnologia Company method is based on successive application of the processes: a) bioconversion; b) biomethanisation; c) aerobic biological treatment; d) physico-chemical treatment, and achieves a treatment yield of the OMW of the order of $99,6 \%$ (Figura 2).

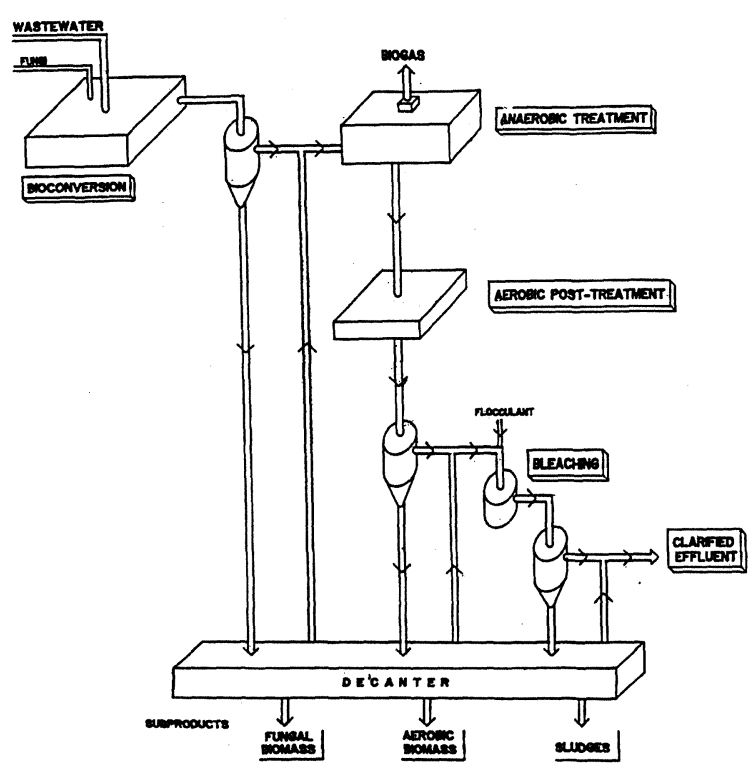

Figure 2

Reuse and integral treatment of olive mill wastewater.

\section{a) Bioconversion}

The main aim of this process is the recovery of the olive oil emulsified with $\mathrm{OMW}$, and elimination of the phenolic compounds which interfere with the biological treatment of this wastewater. Bioconversion achieves:

- The formation of a lipoprotein biomass which "retains" practically all olive oil normally lost with the wastewater.

- The elimination of $70 \%$ of the polyphenol content.

- The elimination of the solids in suspension, colloidal substances, and part of the mineral salts.

Table II shows the average composition of the bio- mass obtained, and Table III the characteristics of the effluent obtained.

\section{Table II}

Average composition of the lipoprotein biomass

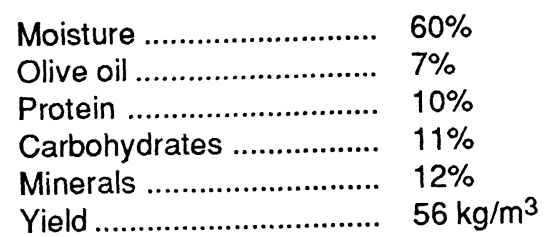

Table III

Characteristics of the effluent from the bioconversion process

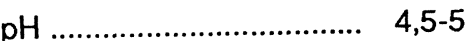

$$
\begin{aligned}
& \text { COD ............................ 20.000-30.000 ppm } \\
& \text { Solids in suspension ........ solid-free }
\end{aligned}
$$

\section{b) Biomethanisation}

The process of anaerobic treatment involves breakdo$w n$ of the organic molecules to methane and carbon dioxide by the symbiotic activity of 3 groups of microorganisms: hydrolytic bacteria, acetogenic bacteria and methanogenic bacteria. From the biotechnological viewpoint, one characteristic of these bacteria is that they do not need attention during periods of digestor inactivity. This is specially relevant to the application of anaerobic treatment processes in seasonal farming-food industries.

This process could well be applied to the particular case of OMW, as the latter's high organic content could produce - at the time as its treatment- sufficient biogas for the energy needs (heating and electric) of the mill, as has been demonstrated by research carried out at the Instituto de la Grasa y sus Derivados, CSIC, Seville, and at the Instituto di Ricerca sulle Acque CNR, Bari, and others.

However, due to the presence in OMW of polyphenols which inhibit microorganisms development, hydraulic retention times in the bioreactors have to be very much higher that those for other wastewaters of the same organic load, resulting in high installation costs.

During anaerobic digestion of the effluent from the lipoprotein biomass procedure, no inhibiting effect is observed, and the process can be carried out with hydraulic retention times lower than 4 days.

Figure 3 shows in graphic form the times needed to achieve complete methanisation of the natural OMW and of the effluent from the obtaining of the lipoprotein biomass. As can be seen, biomethanisation of natural OMW needs times of the order of 36 days, while the effluent (treated OMW) needs only 4 days. 


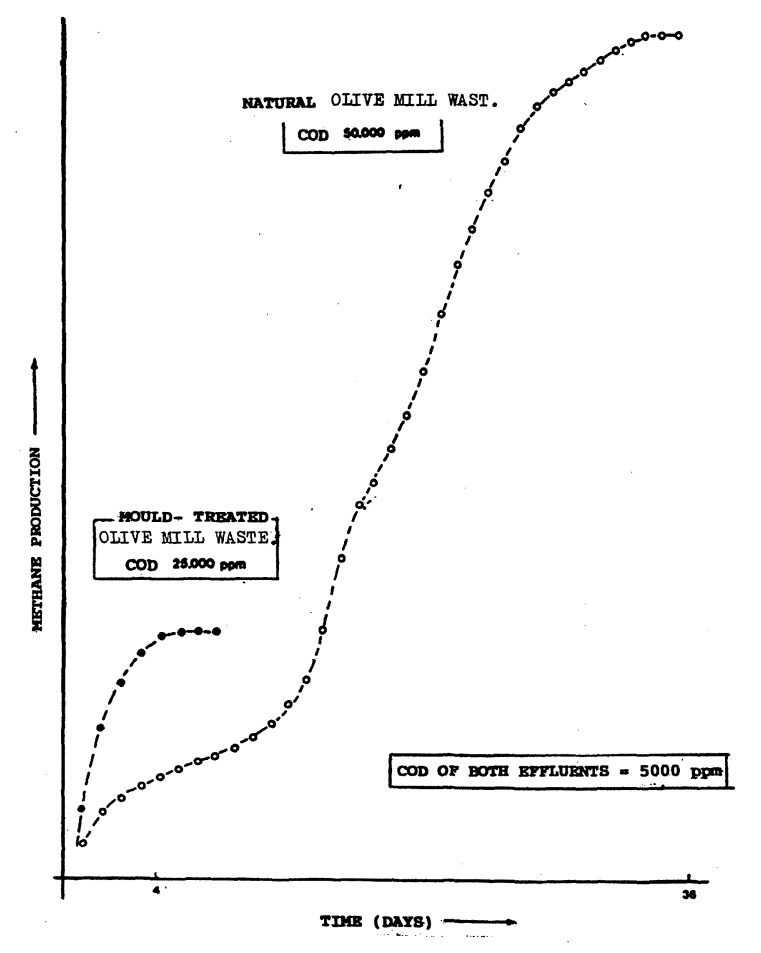

Figure 3

Times necessary for complete biomethanisation of the natural OMW and treated OMW.

Table IV shows the characteristics of the biogas obtained, and Table $V$ those of the anaerobic effluent.

\section{Table IV}

Characteristics of the biogas

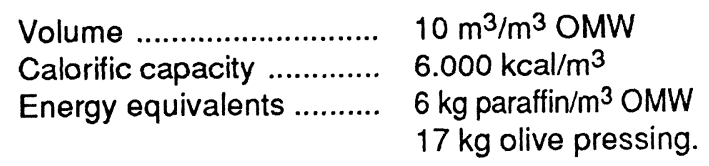

Table V

Characteristics of the anaerobic effluent

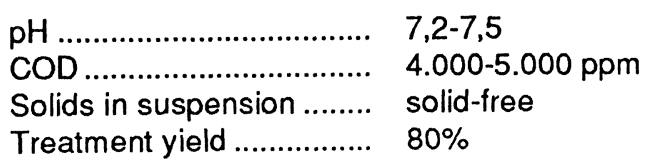

\section{c) Aerobic Biological Treatment}

An active sludge aerobic process was used to reduce the still-high COD of the anaerobic effluent. Table VI shows the characteristics of the aerobic effluent.
Table VI

Characteristics of the aerobic effluent.

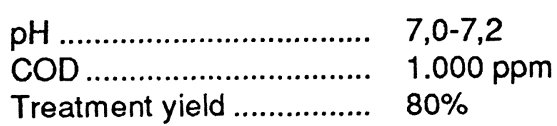

\section{d) Physico-chemical Treatment}

A physico-chemical treatment was used to eliminate coloration of the liquid from the aerobic process, and at the same time reduce its COD. Table VII shows the characteristics of the effluent.

Table VII

Characteristics of the treated olive mill wastewater.

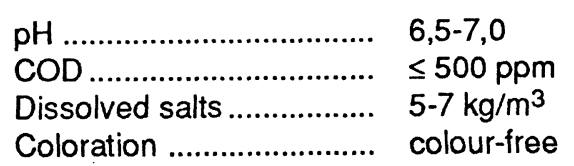

\section{Summary of an integral treatment of OMW by the appli-} cation of biological process.

Figure 4 shows in diagram form the biological process for complete treatment of OMW and the retention times necessary. As can be seen, the complete process of biological treatment can be performed with retention times of only 11 days, with a treatment yield of $99,6 \%$

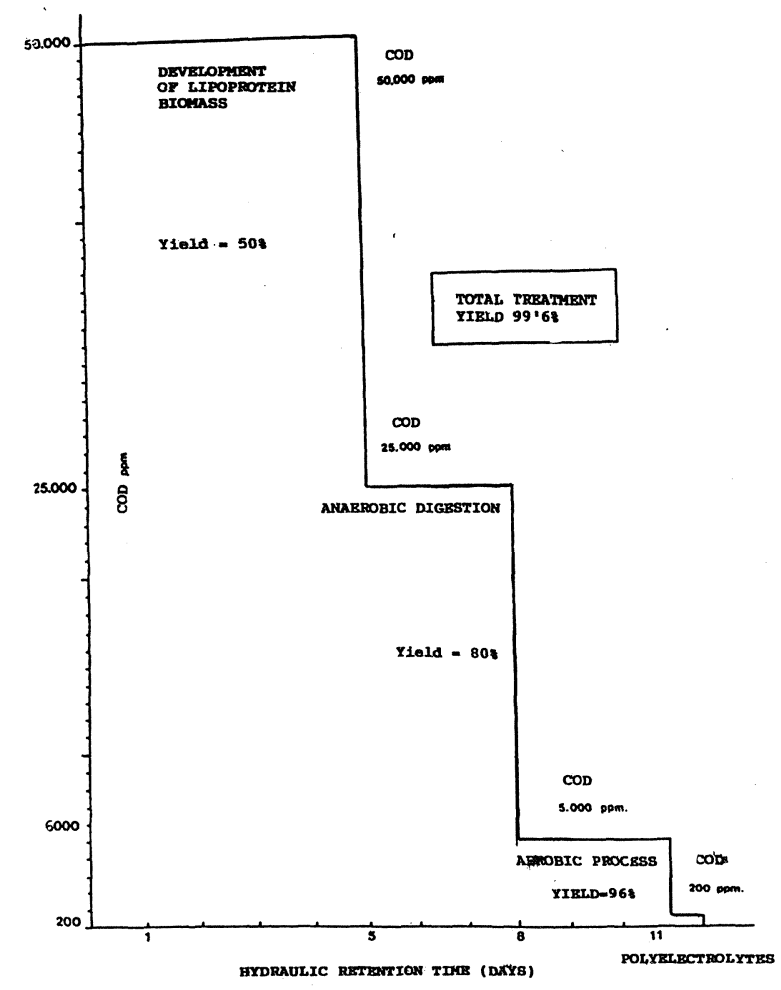

Figure 4

Diagram of integral treatment of OMW by biological process. 
At the same time, the process yields the following by products:

- A lipoprotein which retains all the residual oil lost in the OMW. The obtaining of this biomass could make this phase of the process profitable or self-financing.

- During anaerobic treatment, $10 \mathrm{~m}^{3}$ of biogas $/ \mathrm{m}^{3}$ of treated $\mathrm{OMW}$ is obtained. This constitutes energy of the order of $60.000 \mathrm{kcal} / \mathrm{m}^{3}$ of wastewater.

- A microbial biomass is formed during the aerobic processes, which could be used as animal feed.

\section{REFERENCES}

1. Fedeli, E.- "New perspective for vegetation water and olive residue use".- Proceeding International Symposium on olive by-products valorization, Sevilla, March 1986.

2. Ramos Cormenzana, A.- "Physical, chemical, microbiological and biochemical characteristics of vegetation water".- Proceeding International Symposium on olive by-products valorization, Sevilla, March 1986.

3. De Caro, M. y Galamini Ligori, M.G.- "Attivita antibiótica di un estratto desunto delle acque di vegetazione delle olive".- Rend. Ist. Super Sanita 22 (1959), 223-243.

4. Ragazzi, E.; Veronesse, G et Pietrogrande, A.- "Richerche sui constituenti idrosolubili delle olive I. Zuccheri e fenoli".- Ann. Chim. 57 (1967) 1386-1397.

5. Fleming, H.P. and Etchells, J.L.- "Ocurrence of an inhibitor of lactic bacteria in green olives".- Appl. Microbiol. 15 (1967), 1178-1184.

6. Juven, B. and Henis, Y.- "Studies on the antimicrobial activity of olive phenolic compounds".- J. Appl. Bacteriol 33 (1970) 721-732.

7. Garrido, A. and Vaughn, R.H.- "Utilization of oleuropein by microorganisms associated with olive fermentation".- Can. J. Microbio. 24 (1978), 680-684

8. Federici, F. and Bongi, G.- "Improved method for isolation of bacterial inhibitors from oleuropein hydrolysis".- Appl. Environ. Microbio 46 (1983) 509-510.

9. Moreno, R.; Paredes, M.T. y Martínez, J.- "Efecto de distintas soluciones de alpechín sobre la microflora del suelo".- Res. IX Cong Nac. Microbiol, 1983.

10. Mas, M. y Peinado J.M.- "Phenol effect on the growth of yeast isolated from "alpechín".-- Cien. Biol. (Portugal) 9 (1984), 205-209.

11. Medici, F.; Merli, G. and Spagnoli, E.- "Anaerobic digestion of olive oil mill wastewaters: a new process".- Proceeding Fourth International Symposium on Anaerobic Digestión, Guanzhou (China), 1985

12. Balice, V.; Carrieri, C.; Cera, O. y Di Fazio, A.- "Natural biodegradation in olive mill effluents stored in open basins".- Proceeding Inter national Symposium on olive by-products valorization, Sevilla, March 1986.

13. Balice, V.; Carrieri, C.; Cera, O. and Rindone.- "The fate of tanninlike compounds from olive mill effluents in biological treatments". Proceeding Anaerobic Digestion. 5th International Symposium. Eds. ER. Hall and P.N. Hobson. Pergamon Press, Bologna, 1988.

14. Martínez, J.; Pérez, J.; Moreno, E. y Ramos Cormenzana, A.- "Incidencia del efecto antimicrobiano del alpechín en su posible aprovechamiento".- Grasas y Aceites 37 (1986), 215-223.

15. Sáinz-Jiménez, C.; Gómez-Alarcón, G. y De Leeuw, J.W.- "Naturaleza química del polímero aislado del alpechín fresco y de lodo de balsas de evaporación".- Resumen Simposio Internacional sobre Valoración de los Subproductos del olivar: alpechín y orujo, Sevilla, 1986.
16. Sorlini, C.: Andreoni, V.: Ferrari, A. y Ranalli, A- "The influence of some phenolic acids presents in oil-mill waters on microbic groups for the methanogenesis".- Procceding International Symposium on Olive By-products Valorization, Sevilla, 1986.

17. Borja, R.; Maestro, R.; Martín, A.; Fiestas, J.A. y Alba, J.- "Biodegradación de los compuestos fenólicos presentes en el alpechin".- $R e$ unión Internacional sobre tratamiento de alpechines, Córdoba, 1990.

18. Borja, R.; Martín, A.; Maestro, R.; Fiestas, J.A. y Alba, J.- "Estudio cinético comparativo del proceso de depuración anaerobia del alpechín natural y del previamente tratado por vía aerobia para eliminar su poder inhibidor".- Reunión Internacional sobre tratamiento de alpechines, Córdoba, 1990.

19. Maestro Durán, R. y Borja Padilla, R.- "Influencia de los polifenoles en la depuración del alpechin".- XXIV Asamblea Plenaria de Miembros del Instituto de la Grasa y sus Derivados, 1990

20. Pérez, J.D.; Gallardo, F. y Esteban, E.- "Aspectos a considerar en el empleo del aplechín como fertilizante. I. Evaluación de su efecto fitotóxico inhibidor de la germinación de semillas".- Cuad. Cienc. Biol. 6-7 (1980), 59-67.

21. Flouri, F. Chatijpavlidi and Balis, C.- "Effect of olive oil mills liquid wastes on soil fertility". - Actas Reunión Internacional sobre tratamiento de alpechines, Córdoba, 1990.

22. Zucconi, F. y Bukovac, M.J.- "Analisi sule activita biologica dell'acqua di vegetazione delle olive".- Artcle n.? 4.736. Michigan Agricultural Experiment Station Journal, 1970.

23. Varela, G. y Jordán, J.- "Sobre la toxicidad del alpechin".- Bol. Universidad de Granada. Farmacia 3 (1959), 135-144.

24. Fiestas Ros de Ursinos, J.A.- "Los alpechines y la riqueza piscicola".- Bol. Oleicultura Internacional 42 (1958) 35 y 43 (1958), 27-98.

25. Gómez Herrera, C. y Janer del Valle, C.- "Estudios físico-químicos sobre las pastas de aceitunas molidas. II. Caracteristicas físico-quimicas de alpechines".- Grasas y Aceites 7 (1956) 249-302.

26. Carrieri, C.- "Ultrafiltration of vegetation waters from olive oil extraction plants. I. Preliminary experiences".- Oli Grassi Derivati 14 (1978), 29-32.

27. Boari, G.; Carrieri, C. y Santori, M.- "Depurazione con processi a membrana di acque di vegetazione diversamente pretrattate".- Oli Grassi Derivati 16 (1980) 2-4

28. Vigo, F.; De Paz, M. y Avale, L.- "Ultrafiltrazione di acque di vegetazione da frantoi di olive. Esperienza gestionale in impianto semipilota".- Riv. Ital. Sostanze Grasse 60 (1983), 267-271.

29. Fiestas Ros de Ursinos, J.A.- "Depuración de aguas residuales en las industrias de aceitunas y aceite de oliva".- Grasas y Aceites 28 (1977) 113-121.

30. Oka, T.; Simpson, F.J.; Child, J.J. and Mills, S.- "Degradation of rutin by "Aspergillus flavus".- Purification of the dioxigenase, quercitinase".Can. J. Microbiol. 17 (1971), 111-118.

31. Fedorak, P.M. and Hrudey, S.E.- "The effects of phenol and some alkil phenolics on bath anaerobic methanogenesis".- Water Res. 18 (1984), 361-367.

32. Borja, R.- "Depuración anaerobia del alpechín: Influencia de las características del soporte de inmovilización sobre las constantes biocinéticas".- Tesis Doctoral, 1989.

33. Fiestas, J.A. y Borja, R.- "Aprovechamiento y depuración integral de alpechin".- RETEMA. Revista Técnica del Medio Ambiente 5 (1988) 97-100.

(Recibido: Junio 1991) 